\section{LIBERDADE E SOLIDARIEDADE: \\ visões sobre o cativeiro em um julgamento afro-baiano do século XVII}

Freedom and solidarity: visions of captivity in a $17^{\text {th }}$ century African trial in Bahia
Alexandre Almeida

\section{MARCUSSI $^{*}$}

(iD) alexandremarcussi@gmail.com

*Universidade Federal de Minas Gerais

Belo Horizonte, MG, Brasil

\section{RESUMO}

Este artigo consiste em uma leitura do processo inquisitorial de Simão, africano liberto nascido no Congo e residente no Recôncavo Baiano no final do século XVII. Simão foi denunciado ao Santo Ofício de Lisboa em 1685 após ser acusado pelo proprietário André Gomes de Medina e por seus escravos de matar outros cativos com feitiços. Antes de ser remetido à inquisição, foi informalmente julgado na propriedade de André de Medina e condenado como feiticeiro em uma cerimônia judiciária e religiosa de origem africana, conduzida por uma sacerdotisa chamada Grácia, praticante de calundus. A interpretação do julgamento de Simão conduzido pelos escravos intenta evidenciar as concepções de culpa, inocência e de liberdade no seio da comunidade escrava da região. A partir da análise, sugiro que muitos cativos africanos exerceram uma forma ideológica de resistência à escravidão que não se pautava na reivindicação da liberdade, em termos modernos, mas sim na defesa de um ideal caracteristicamente africano de solidariedade.

Palavras-chave: calundu, resistência escrava, Inquisição, religiões afro-brasileiras

\begin{abstract}
This paper presents an interpretation of the process of Simão in the Portuguese Inquisition. Simão was an African freedman born in the Kingdom of Kongo who lived in Bahia in the last decades of the 17th century. Simão was denounced to the Inquisition in 1685 after having been accused by slave-owner André Gomes de Medina and by Medina's slaves of performing witchcraft to kill other Medina's captives. Before being sent to the Inquisition, Simão had already been informally judged and condemned in André de Medina's lands by means of a judicial and religious ceremony conducted by an African priestess named Grácia, who was a practitioner of an African-American cult called "calundu". The analysis of Simão's trial by African slaves aims at shedding light on concepts of guilt, innocence, and freedom that existed in the Bahian African community at the time. I argue that many African slaves have engaged in a kind of ideological resistance to slavery which did not conform to a paradigm based on the demand for liberty, in modern terms, but which instead was built upon a characteristically African understanding of solidarity.
\end{abstract}

Keywords: calundu, slave resistance, Inquisition, African-American religion 
No dia 17 de fevereiro de 1689, na Casa do Despacho da Inquisição de Lisboa, compareceu perante a mesa do Santo Ofício, para receber a sentença final de seu processo, o réu Simão. O processado nascera no reino do Congo e, à época de sua prisão, era residente na freguesia de Santo Amaro da Pitanga, no Recôncavo Baiano, na condição de alforriado. Contrariamente ao que ocorria com a maioria dos réus inquisitoriais, Simão não ouviu sua sentença em auto de fé público, perante as multidões que se reuniam em Lisboa, usualmente no Terreiro do Paço, diante do palácio real, para assistir aos elaborados rituais nos quais a inquisição punia seus condenados, no intuito de reafirmar publicamente sua autoridade, advertir os fiéis acerca dos perigos do desvio religioso e purificar simbolicamente o corpo espiritual do reino (SARAIVA, 1985, p. 110-112; NOVINSKY, 1994, p. 66-70). Simão foi chamado a ouvir sua sentença apenas diante dos inquisidores, em cerimônia privada. ${ }^{1}$ Depois de uma recapitulação de seus supostos crimes e dos argumentos constantes de sua defesa, os inquisidores Sebastião Diniz Velho e João Muniz da Silva deram-lhe a sentença final, segundo a qual "absolvem ao réu Simão preto da instância do juízo". ${ }^{2}$ Coube-lhe, é bem verdade, o pagamento dos custos processuais; mas ao menos fora poupado da pena habitual para réus como ele, que consistia em degredo e exílio permanente de seu local de residência. Saía do tribunal livre para ir para onde bem entendesse.

Era uma sentença incomum. Não era, contudo, inédita: Simão não foi o único réu da inquisição a ser inocentado, nem mesmo o único escravizado 3 acusado de feitiçaria a escapar da pena. Mas, sem dúvida, a absolvição era uma conclusão invulgar nos processos inquisitoriais, em grande medida porque a processualística da inquisição não a facilitava. O processo criminal era concebido para espelhar o sacramento da confissão, cabendo ao réu, no mais das vezes, confessar seus supostos crimes para poder ser reconciliado com Deus pelos inquisidores ( $\mathrm{MARCOCCl}$, 2012). Dessa forma, o processo normalmente consistia em mera confirmação, da boca do acusado, dos crimes pelos quais ele havia sido denunciado. Uma vez acatada a denúncia pelo tribunal, dificilmente se escapava dessa lógica confirmatória. Por conta dessa forma de funcionamento dos tribunais inquisitoriais, quando o réu era declarado inocente, isso normalmente resultava do fato de que sua denúncia inicial havia sido considerada de alguma forma inadequada ou inválida pelos inquisidores responsáveis.

Foi o caso de Simão. A denúncia contra o acusado havia sido remetida ao Santo Ofício em 1685, pelo carmelita Frei Domingos das Chagas. O acusado já havia sido encarcerado no aljube episcopal antes mesmo da deliberação do tribunal inquisitorial sobre sua denúncia, o que contradizia o procedimento regulamentar. A verdade é que a denúncia ao Santo Ofício visava apenas corroborar oficialmente um julgamento informal que já havia sido realizado na Bahia. Simão fora considerado feiticeiro, acusado de matar com feitiços quinze escravos de André Gomes de Medina, em Santo Amaro da Pitanga. A acusação partira do conjunto dos escravos sobreviventes de André de Medina, tendo sido corroborada e ratificada por uma outra escravizada africana chamada Grácia, convocada de sua residência em Cotegipe pelo proprietário prejudicado especificamente para determinar o culpado da mortandade. Grácia tinha fama de curandeira e adivinha na região, e presumia-se que seria capaz de identificar, por vias espirituais, o responsável pelas mortes, o que ela fez por meio de uma cerimônia de consulta aos espíritos acompanhada de cantos e orações no idioma quicongo (falado na região do reino do Congo, no continente africano). Portanto, quando 
o réu chegou ao tribunal inquisitorial em Lisboa, ele já havia sido condenado por um julgamento religioso presidido por uma africana e corroborado por um senhor de escravos enfurecido com a perda de seu capital. Pedia-se à Inquisição, na prática, que encampasse a condenação e procedesse à atribuição de uma pena institucional.

O procedimento todo parecera irregular aos olhos dos inquisidores. As provas contra o acusado eram frágeis. É verdade que o processo contava com oito testemunhos contra Simão, quatro dos quais provenientes de eclesiásticos ou membros da família Medina pessoas de respeitabilidade social, que podiam ser consideradas testemunhas qualificadas de acordo com o procedimento inquisitorial. Simão havia aparentemente confessado o crime, embora André de Medina, o senhor lesado pelos supostos feitiços do alforriado, fosse o único que ouvira a confissão, além de seus escravos (cujo testemunho era considerado menos digno de crédito para o Tribunal da Inquisição). O maior problema formal do processo advinha do fato de que a mais importante prova contra o réu havia sido obtida em uma cerimônia religiosa realizada pela escrava africana Grácia por meios considerados diabólicos, o que na prática esvaziava a denúncia de credibilidade diante do Santo Ofício. Dois fatores, portanto, explicam a absolvição de Simão: em primeiro lugar, as imperfeições formais da acusação; em segundo lugar, e talvez até mais decisivamente, a presunção de que André Gomes de Medina e seus escravos estivessem usurpando as atribuições inquisitoriais ao procederem, eles mesmos, ao julgamento de Simão. ${ }^{4}$

Em qualquer caso, o que nos interessa aqui é muito menos o julgamento dos inquisidores e muito mais aquele realizado pelos escravos, que unanimemente atribuíram a culpa pelas mortes a Simão. O acusado pode ter saído livre do julgamento inquisitorial, mas foi condenado maciçamente pelos seus companheiros de cativeiro. O que motivara as acusações? Qual fora o papel da cerimônia religiosa de Grácia na percepção da culpa de Simão? Essas questões talvez nos forneçam algumas indicações para refletirmos sobre as concepções de justiça, de liberdade e de harmonia social no interior da comunidade africana da Bahia no final do século XVII.

\section{O calundu de Grácia}

Uma narrativa mais detalhada da trajetória de Simão e do julgamento realizado por Grácia pode nos ajudar a entender melhor a percepção dos escravos de Santo Amaro da Pitanga acerca de sua culpa. Simão nasceu no reino do Congo, por volta de 1648, e foi levado "muito menino de Angola para a Bahia"5 como escravo. Sendo assim, na época dos eventos que levaram à sua denúncia, Simão estava muito longe de ser um africano recém-desembarcado no Brasil. É provável que ele tenha chegado ao Brasil por volta de 1660 - possivelmente antes $-^{6}$ e que, portanto, já tivesse pelo menos vinte e cinco anos de experiência em solo luso-americano, sendo um "ladino", como eram denominados os africanos que dominavam a língua portuguesa e os códigos culturais e sociais lusoamericanos. Também já não era mais escravo em 1685, quando foi denunciado. O processo inquisitorial não nos diz quando Simão obteve sua alforria, mas evidencia que ele havia sido escravo de André Machado e de seu genro Manuel Madeira, e que na época de sua denúncia era forro lavrador de uma roça de mandioca em Santo Amaro da Pitanga. Sua roça se localizava na propriedade de Maria Cabral, filha de André Gomes de Medina, o 
proprietário cujos escravos haviam supostamente morrido em decorrência de malefícios atribuídos a Simão. Curiosamente, a denúncia originalmente remetida ao Santo Ofício e os testemunhos contra o africano reiteradamente o descrevem como "escravo" de Maria Cabral, mas é seguro que ele já era forro a esta altura. Voltaremos mais adiante a este detalhe, aparentemente desimportante mas absolutamente revelador.

Entre 1684 e 1685, onze dos escravos de André Gomes de Medina, pai de Maria Cabral (para quem Simão trabalhava como lavrador), morreram de forma misteriosa, de doenças desconhecidas. Diante de tamanha sucessão de tragédias, suspeitava-se de feitiços, diagnóstico corriqueiro na cultura luso-americana da época (RIBEIRO, 2003; NOGUEIRA, 2012). É provável que as mortes tivessem causado uma atmosfera de indignação e terror entre os escravos de André de Medina. Os parentes dos escravos mortos clamavam por justiça e pela punição do feiticeiro supostamente responsável pelas mortes, ao mesmo tempo em que os escravos sobreviventes temiam por sua saúde e suas vidas. O proprietário tampouco estava contente, já que via seu capital definhar sob seus olhos.

Em seu testemunho ao Santo Ofício, André Gomes de Medina contou que foram seus escravos - especialmente aqueles que tinham parentes entre os falecidos - que Ihe indicaram alguém que seria capaz de resolver a questão. Tratava-se de uma africana chamada Grácia, escrava do sargento Marcos de Bitencourt e residente na freguesia de Cotegipe, na parte leste do Recôncavo Baiano, a uma distância de cerca de $50 \mathrm{~km}$ da propriedade de André de Medina. Segundo as testemunhas, Grácia tinha fama de "curandeira"7 e de "feiticeira", além da reputação de que "adivinhava os que faziam feitiços". ${ }^{8}$ Grácia nascera no reino do Congo, mesma região de origem de Simão. A alegação de que ela era reputada curandeira e adivinha nos indica que ela era provavelmente uma sacerdotisa de um tipo de manifestação religiosa cuja matriz cultural advinha da África Centro-Ocidental (macrorregião que englobava o reino do Congo), e que viria a ser conhecida na Bahia, a partir do final do século XVII, pela denominação de "calundu".

Calundus eram cerimônias religiosas majoritariamente terapêuticas, mas que envolviam também dimensões divinatórias. Nelas, doentes de várias moléstias eram diagnosticados por meio da intervenção de entidades espirituais (frequentemente com a possessão do corpo do sacerdote pelo espírito patrono do culto), que indicavam a causa das doenças e os remédios adequados a cada aflição. Os calundus eram procurados por negros e brancos, escravos e livres, principalmente para fins terapêuticos, mas eventualmente os calunduzeiros podiam ser consultados apenas por sua capacidade de adivinhar coisas ocultas por meio da intervenção espiritual (SOUZA, 1986; 2002; SWEET, 2003; MARCUSSI, 2015). Assim sendo, calunduzeiros como Grácia eram "curandeiros" e também "adivinhos" - o que, aos olhos dos eclesiásticos, os qualificava enfim como "feiticeiros". A palavra "calundu" deriva do termo quilundo, que no idioma quimbundo designava os espíritos que possuíam o corpo dos sacerdotes do povo jaga, conhecidos como xinguilas, ${ }^{9}$ e o termo provavelmente começou a ser usado na América no último quartel do século XVII. O fato de que o ritual de Grácia não foi explicitamente denominado pelo termo "calundu" se explica por dois fatores. Em primeiro lugar, é só a partir da década de 1690 que a palavra começa a se disseminar no vocabulário inquisitorial. Em segundo lugar, e provavelmente com maior relevância, Grácia era falante de quicongo, o que significa que ela muito provavelmente 
dava outro nome a suas cerimônias, no lugar do termo de etimologia quimbunda que viria a se celebrizar na América Portuguesa. ${ }^{10}$

Segundo André de Medina, Grácia fora chamada especificamente para que adivinhasse o autor dos feitiços que haviam supostamente provocado a morte de seus escravos. Contudo, André e seus escravos não ficaram passivamente esperando pelo julgamento de Grácia. Já tinham um suspeito pelas mortes: Simão. O padre Martim Pessoa, capelão da propriedade de André de Medina, fora à casa habitada por Simão e lá encontrara panelas supostamente contendo ervas, unhas, dentes e cabelos de animais e pessoas, o que apenas reforçara a presunção geral acerca da culpa do liberto. Perante os inquisidores, Simão alegou que as panelas em sua casa continham apenas pós preparados a partir das cabeças de cobras, que eram usados como antídotos naturais para picadas de jararacas - procedimento que aprendera com seu antigo senhor Manuel Madeira. ${ }^{11}$ Qualquer que fosse o caso, quando Grácia chegou à propriedade para realizar sua cerimônia divinatória, encontrou o suspeito Simão já preso a um tronco para aguardar seu julgamento. ${ }^{12}$

Grácia trouxera consigo intérpretes para poder se comunicar com a escravaria de André de Medina, já que ela falava quicongo, enquanto a língua geral da escravaria era o quimbundo, evidenciando a alta concentração de africanos da região de Angola na propriedade. ${ }^{13}$ Grácia devia ser uma escravizada recém-chegada à América, ainda incapaz de se comunicar competentemente em um idioma que os escravos compreendessem (o quimbundo ou o português). Mesmo assim, já adquirira fama pela região do Recôncavo Baiano, tinha permissão de seu senhor para se deslocar a outras propriedades para fazer suas cerimônias e podia até mesmo levar intérpretes que a ajudassem a se comunicar com os senhores e os escravos. É provável que Marcos de Bitencourt, seu proprietário, a visse como uma fonte de renda e a alugasse para outros senhores de escravos, talvez permitindo à escrava manter para si uma parte dos rendimentos. Tratava-se de um arranjo muito comum entre senhores e seus escravos curandeiros, visto que calunduzeiros eram frequentemente contratados por proprietários de escravos para curar moléstias de escravos que nem os padres, nem os médicos conseguiam curar (MARCUSSI, 2015, p. 339346). Havia até mesmo a percepção, em alguns contextos, de que os calunduzeiros seriam especialmente aptos a curar as moléstias da escravaria, como expressou o frei Luís de Nazaré, o qual, chamado para exorcizar uma escrava chamada Tomásia em meados do século XVIII, recomendou a seus senhores "que a mandassem aos curadores chamados calunduzeiros, porquanto [...] os exorcismos não tiravam aquela casta de feitiços" (Apud SOUZA, 1986, p. 263). Uma vez que os calunduzeiros muitas vezes compartilhavam em boa medida o repertório cultural dos escravos doentes, não é difícil compreender que sua terapêutica tivesse maior eficácia entre os cativos do que os métodos empregados por outros agentes da saúde na sociedade luso-americana, como médicos ou eclesiásticos.

Portanto, não constituía fato excepcional que André de Medina tivesse mandado chamar uma sacerdotisa africana para resolver o incidente envolvendo seus escravos. $O$ que ele provavelmente não sabia era que, para além de resolver o problema do proprietário prejudicado, Grácia estava lá também - talvez de forma menos evidente - para atender aos interesses divergentes dos escravos da propriedade. Vejamos como o proprietário descreveu à Inquisição o método empregado por Grácia para realizar a adivinhação do culpado pelas mortes: 
[...] a cerimônia de que usou foi pôr sobre três paus uma panela de água e, subministrando-lhe por baixo o fogo, começou a panela a ferver. E cantou umas palavras na sua língua, que se não entenderam por ela ser conga, e não ser a língua geral do gentio da Guiné. Depois, estando a panela fervendo, mandou meter a mão dentro da panela aos escravos que presentes estavam, os quais as tiraram ilesas, sem se queimarem. E, mandando meter também dentro da panela a mão ao [...] escravo Simão, a tirou toda queimada, a qual teve por tempo de dois meses em chagas, e ainda hoje traz os sinais. E ouviu ele testemunha dizer aos seus escravos que o dito Simão, diante deles, confessara que havia morto com feitiços os escravos dele testemunha e muitos de outras pessoas vizinhas, que, por todos, eram mais de quarenta. ${ }^{14}$

Na verdade, não bastou aos acusados simplesmente pôr a mão na água fervente. De acordo com o testemunho do padre Martim Pessoa, Grácia adicionara à panela de água uma argola de ferro que usava no braço, e os suspeitos deviam retirar a argola de dentro da água. Aqueles que fossem inocentes seriam poupados das queimaduras:

E a cerimônia de que [Grácia] usou foi que fincou três paus no chão, capazes de poderem sustentar uma panela de água, e subministrando-lhe fogo de baixo, começou a ferver a panela. E, lançando-lhe dentro um ferro e dizendo umas palavras que se não perceberam, mandou a todos, um por um, que metessem a mão dentro da dita panela e tirassem o ferro. E, receando queimarem-se, Ihas assegrou que se não haviam de queimar se estavam inocentes. ${ }^{15}$

Conforme apontado por James Sweet (2003, p. 120-123), a cerimônia de Grácia reproduzia quase perfeitamente os procedimentos empregados em uma cerimônia judiciária praticada na África Centro-Ocidental no século XVII, conhecida como jaji. O jaji foi observado e relatado em meados do século pelo missionário capuchinho italiano João Antônio Cavazzi de Montecúccolo:

No juramento chamado jaji [...] o feiticeiro [...] deita numa panela água, uma pedra e terra avermelhada com uns pedaços de cabaça usada para conservar azeite. Quando a água ferve, obriga o acusado a tirar a pedra com a mão. Se ficar queimado, é julgado como réu; se não receber prejuízo, cada um dos presentes o aclama inocente, sem mais inquérito. (CAVAZZI DE MONTECÚCCOLO, 1965, v. 1, p. 109)

As diferenças eram pontuais e pouco relevantes: a cerimônia de Grácia empregava uma argola de ferro, enquanto o jaji observado por Cavazzi usava uma pedra para o mesmo fim. A terra avermelhada e os pedaços de cabaça não figuravam no rito de Grácia - ou não foram descritos pelas testemunhas, que talvez os tenham considerado como meros detalhes desimportantes. Qualquer que seja o caso, é patente a semelhança formal entre os dois ritos.

O jaji estava longe de ser uma cerimônia idiossincrática: pelo contrário, ritos judiciários semelhantes eram muito disseminados em todas as regiões da África Centro-Ocidental visitadas por Cavazzi, englobando o reino do Congo, o reino de Angola (ao sul do primeiro) 
e territórios no interior, como o reino de Matamba. Os procedimentos específicos variavam enormemente, mas o princípio mantinha-se o mesmo: os suspeitos de um crime eram submetidos a uma espécie de teste de inocência presidido por um juiz-sacerdote, que invocava os espíritos para determinar a culpa ou inocência de cada suspeito. Os espíritos invocados deviam se manifestar no resultado do teste: se o suspeito fosse inocente, passaria ileso; se fosse culpado, sofreria algum tipo de sofrimento ou ferimento físico. Em muitos casos, o teste conduzia à morte daqueles considerados culpados, de modo que a pena capital já se executava automaticamente, como era o caso dos testes de inocência baseados na ingestão de venenos. Cavazzi descreve os testes do ncassa (em que o suspeito era obrigado a ingerir uma bebida feita com o pó da casca da árvore ncassa, que era venenosa, tendo de vomitá-la para provar sua inocência), do oroncio (em que uma banana envenenada fazia o mesmo papel da bebida do ncassa), do mbulungu (em que o acusado tinha de se provar capaz de engolir uma raiz de bananeira de difícil deglutição) e do mbau (em que um ferro em brasa era aplicado à pele do acusado, que ficaria supostamente ilesa caso ele fosse inocente) (CAVAZZI DE MONTECÚCCOLO, 1965, v. 1, p. 103-108). Em todos os casos, a lógica era a mesma: o juiz-sacerdote invocava os espíritos para que eles determinassem a culpa pelo crime cometido, e esses espíritos manifestavam-se por meio do objeto ou procedimento empregado na cerimônia.

Apesar das diferenças aparentes, a lógica subjacente às cerimônias terapêuticas dos calundus e a cerimônias judiciárias como o jaji realizado por Grácia era a mesma, embora o objetivo imediato fosse distinto: nos calundus, tratava-se de curar um enfermo; no jaji, por sua vez, tratava-se de determinar e punir um suspeito por um crime cometido. Nos dois casos, o sacerdote invocava a intervenção de entidades espirituais para que elas revelassem uma informação desconhecida (a origem das doenças, ou o culpado de um crime) e resolvessem um problema concreto. As semelhanças, contudo, não se limitam apenas ao caráter divinatório de ambos os ritos. Para entendermos melhor o parentesco entre os calundus e ritos judiciários como o jaji, é preciso compreender as concepções cosmológicas de harmonia e bem-estar social que presidiam ambos os tipos de cerimônia nas culturas oriundas da África Centro-Ocidental.

A despeito das diferenças regionais, o sistema religioso centro-africano, entre os povos falantes de quicongo e quimbundo, exibia algumas regularidades relevantes, e incluía uma diversidade de cerimônias e cultos dedicados a diferentes tipos de espíritos, como os antepassados ou os espíritos da natureza (MACGAFFEY, 1986), com papel fundamental desempenhado pelas revelações oriundas do mundo espiritual (THORNTON, 2004, p. 312-354), como aquelas que se manifestavam em cerimônias como o jaji ou os calundus. Ademais, vigorava nas populações que habitavam essa região aquilo que antropólogos denominaram "complexo da fortuna-infortúnio" (CRAEMER; VANSINA; FOX, 1976), uma concepção segundo a qual o bem-estar coletivo e a saúde seriam a condição normal da sociedade, denotando uma relação harmoniosa e bem regulada entre os vivos e os espíritos. Por contraste, os infortúnios, as desgraças coletivas, a doença e a morte súbita eram sempre concebidos como resultados de uma ação maligna realizada por alguém mal-intencionado, frequentemente um feiticeiro em aliança com espíritos maliciosos (THORNTON, 2002). Sempre que esses infortúnios coletivos ou individuais se verificassem, cabia aos sacerdotes combatê-los com o auxílio de entidades espirituais propiciatórias. 
No caso da terapêutica associada aos calundus, a doença era vista como uma manifestação de espíritos (MARCUSSI, 2015, p. 92-102), cabendo ao curandeiro reverter a anomalia e restabelecer a saúde do enfermo. O caso do jaji é semelhante. Lembremo-nos de que Simão foi julgado por Grácia como feiticeiro, acusado de matar escravos invocando o poder de espíritos malignos. Para a concepção centro-africana, parecia impensável que uma tragédia coletiva, como as sucessivas e inexplicáveis mortes de escravos na fazenda de André Gomes de Medina, pudesse ser encarada de qualquer outra maneira que não manifestação de uma poderosa feitiçaria. O jaji de Grácia não tinha como objetivo exclusivo indicar um culpado: para além disso, ele visava desmascarar um feiticeiro e impedi-lo de causar novas desgraças. Nesse sentido, calundus e ritos como o jaji, a despeito de suas aparentes diferenças de objetivo, funcionavam exatamente a partir do mesmo princípio: as causas espirituais de um infortúnio (a doença individual, no caso dos clientes de calundus, e a morte de mais de dez escravos em circunstâncias misteriosas, no caso do julgamento de Simão) eram determinadas por uma intervenção espiritual, seguida de um procedimento ritualístico para combater a anomalia espiritual responsável pela tragédia, e restaurar a harmonia e o bem-estar (a cura da doença, no caso dos calundus, e a prisão e julgamento do feiticeiro, no caso do jajii). Ainda que um rito resultasse na preservação da vida do doente e o outro possivelmente na morte do culpado, tratava-se de uma diferença que refletia a inversão da situação inicial: no caso dos calundus, os aflitos ainda se encontravam vivos; no caso dos malefícios provocados por um feiticeiro, suas vítimas já estavam mortas.

Nesse sentido, reforça-se a hipótese sugerida anteriormente de que Grácia tivesse fama de calunduzeira pela região, já que era publicamente conhecida como adivinha e curandeira. O jaji que ela realizou em Santo Amaro não passava de uma variação de suas curas, dentro do mesmo sistema cultural dos calundus centro-africanos. É como curandeira, aliás - isto é, como alguém capaz de regenerar uma comunidade em uma situação de infortúnio - que ela havia sido indicada a André de Medina pelos seus escravos. Cabe, portanto, a questão: o que os escravos percebiam como sendo a "doença" que Grácia foi convocada a curar? A resposta a esse problema pode nos ajudar a iluminar alguns aspectos sobre a maneira como os escravizados encaravam a situação do seu cativeiro e as possibilidades de resistência ou oposição a ele.

\section{"Uns bichos que the ferviam na cabeça"}

Simão estava, portanto, sendo acusado de ser um feiticeiro e de ter matado mais de dez escravos com feitiçarias. O que ele próprio achava dessas acusações? Diante do tribunal do Santo Ofício, desmentiu tudo o que se lhe imputava, e afirmou que a única coisa que fazia era preparar e ministrar antídotos naturais contra picadas de cobras venenosas. Contudo, tanto André de Medina quanto seus escravos declararam, em seus testemunhos no sumário de culpas conduzido pelo carmelita Frei Domingos das Chagas em 1687, que Simão confessara ter matado mais de quarenta escravos com feitiços, somando-se os de André de Medina e os de outros proprietários da região. Será que Simão estaria meramente tentando negar diante dos inquisidores a confissão que fizera antes?

Em sua confissão ao Santo Ofício, Simão explicou o método pelo qual a cerimônia realizada por Grácia indicara sua culpa, não sem antes esclarecer - esperteza de réu - que não consentira em participar do rito supostamente diabólico e que só o fizera por ter sido 
obrigado. Já vimos em que consistia o procedimento de Grácia: todos os suspeitos, um a um, tinham de submergir a mão em uma panela com água fervente para dela tirar uma argola de ferro sem sofrer queimaduras. Aos olhos do leitor do século XXI, imbuído de um olhar supostamente "científico", pareceria implausivel que qualquer um pudesse obter sucesso no teste. Mas o fato é que nenhum dos escravos presentes sofreu queimaduras, enquanto Simão ficou com queimaduras severas que the deixaram sequelas permanentes. Segundo André de Medina, depois que Grácia "mand[ou] meter também dentro da panela a mão ao dito escravo Simão, a tirou toda queimada, a qual teve por tempo de dois meses em chagas, e ainda hoje traz os sinais [isto é, cicatrizes]". ${ }^{16}$ Simão, em seu depoimento ao Santo Ofício, esclareceu como se obtiveram resultados tão disparatados a partir de um mesmo procedimento aplicado a todos os suspeitos:

[...] metendo todos a mão na panela, o fizeram só por uma vez, muito levemente [talvez sem nem tirar a argola de ferro do fundo da panela?], em forma que se não queimaram. Porém, ele réu, cuidando [que] melhor mostrava a sua inocência, meteu a mão na dita panela por seis ou sete vezes, e de todas tirava uma pedra [a argola de ferro?] que estava no fundo da dita panela. E assim se escaldou na mão, do que resultou entenderem os circunstantes, ou dizerem que o presumiam, que com a dita experiência ficava confirmada a opinião de que ele réu era feiticeiro, o que ele réu sempre negou. ${ }^{17}$

Por que essa disparidade no tratamento dos diferentes suspeitos? Segundo Simão, ele agira com tamanha veemência "cuidando que melhor mostrava a sua inocência". Não devemos, contudo, entender que a extravagante e perigosa repetição do teste tenha sido voluntária e espontânea da parte de Simão. Lembremo-nos de que ele já havia sido apontado como culpado e, quando Grácia chegou para realizar sua cerimônia, já se encontrava agrilhoado a um tronco. Supunha-se, coletivamente, que ele seria o culpado, e Grácia era incumbida na verdade de confirmar ritualmente essa culpa presumida. Daí a insistência para que o acusado, diferentemente de todos os demais presentes, submergisse completamente a mão na água fervendo várias vezes, alcançando a argola de ferro no fundo da panela. A cerimônia fora montada de forma a corroborar a opinião coletiva e confirmar o consenso estabelecido, o que era frequente nas adivinhações centro-africanas (SWEET, 2003, p 119), e o rito permitia variações sutis mas cruciais para garantir ao sacerdote uma certa medida de controle sobre o resultado.

As cerimônias judiciárias observadas pelo missionário capuchinho Cavazzi de Montecúccolo na África Centro-Ocidental apresentavam procedimentos análogos de aplicabilidade seletiva do teste. No caso do jaji centro-africano, segundo Cavazzi, o sacerdote untava a mão de cada participante com uma substância antes que ele a submergisse na água: se quisesse que o suspeito se queimasse, aplicava uma substância que aumentava a sensibilidade ao calor; em caso contrário, aplicava uma pomada com virtudes protetoras contra queimaduras. O mesmo artifício era empregado no caso do teste com a chapa de ferro quente. No caso dos testes envolvendo venenos, era comum que o juiz-sacerdote ministrasse antídotos para proteger alguns suspeitos da toxicidade da substância ingerida (CAVAZZI DE MONTECÚCCOLO, v. 1, p. 106-109). O procedimento empregado por Grácia parecia ser uma versão mais simplificada, mas com igual eficácia. 
Não quero com isso sugerir que testes de inocência centro-africanos, como aquele que foi empregado por Grácia em Santo Amaro da Pitanga, fossem embustes ou meros esquemas fraudulentos. Essa era, evidentemente, a perspectiva defendida pelo missionário Cavazzi em suas pregações e em sua obra, já que seu objetivo era o de desmascarar sacerdotes que, em sua perspectiva, eram enganadores ou estavam aliados a forças diabólicas. Nesse sentido, curiosamente, explicações "racionalistas" desses ritos, elaboradas a partir de um ponto de vista pretensamente "científico" e moderno, podem convergir perfeitamente com as explicações providencialistas de missionários católicos do século XVII. Essas explicações, contudo, não nos ajudam a elucidar o sentido social e cultural dessas práticas e sua efetividade no seio de uma comunidade, nem tampouco nos auxiliam a entender as concepções dos africanos que delas participam. Afinal de contas, conforme Lévi-Strauss sugeriu, a efetividade social dos ritos mágicos se fundamenta numa crença tríplice:

[...] a eficácia da magia implica na crença da magia, e [...] esta se apresenta sob três aspectos complementares: existe, inicialmente, a crença do feiticeiro na eficácia de suas técnicas; em seguida, a crença do doente que ele cura, ou da vítima que ele persegue, no poder de próprio feiticeiro; finalmente, a confiança e as exigências da opinião coletiva, que formam a cada instante uma espécie de campo de gravitação no seio do qual se definem e se situam as relações entre o feiticeiro e aqueles que ele enfeitiça. (LÉVISTRAUSS, 1985, p. 194-195)

É esse "campo de gravitação" constituído pelas expectativas da opinião coletiva que mais nos interessa aqui. Entender as configurações desse substrato cultural englobante é o que nos permite, em última instância, compreender por que a cerimônia "funcionava" e qual seu sentido dentro daquela sociedade. E é esse procedimento, alheio às preocupações de missionários como Cavazzi ou dos inquisidores do Santo Ofício, que nos permitirá entender as noções subjacentes de culpa e inocência operantes no interior da comunidade africana de Santo Amaro, que conferiram eficácia social ao rito de Grácia e lhe atribuem inteligibilidade.

O próprio Simão parece ter ficado um tanto confuso a respeito de sua culpa ou inocência. Por um lado, parecia saber que não havia deliberadamente feito feitiços para matar escravos. Contudo, quem poderia lhe garantir que seu espírito não havia vagado durante o sono, associando-se a entidades malignas e provocando o mal, transformando-o inadvertidamente em feiticeiro? Como esclarece Wyatt MacGaffey (1986), era comum entre os bacongos (habitantes da região que inclui o território do antigo reino do Congo, onde Grácia e Simão haviam nascido) que crimes ou transgressões praticados durante o sono (na forma daquilo que nós entenderíamos como "sonhos") fossem concebidos como ações efetivamente realizadas pelos espíritos dos indivíduos enquanto seus corpos dormiam, implicando um reconhecimento de sua responsabilidade por essas ações. ${ }^{18}$ Os bacongos pareciam compreender algo semelhante à noção que Freud viria a formular muito mais tarde, segundo a qual os sonhos seriam veículos para a expressão e elaboração de desejos reprimidos e inconfessáveis. Nesse âmbito, que expressa as angústias coletivas de um grupo social, encontramos elementos do "campo de gravitação" que dava sentido 
e eficácia ao ritual, e que nos permite elucidar aspectos da experiência dos escravizados africanos na América Portuguesa do século XVII.

Pode ser que a acusação coletiva contra Simão e seu fracasso no teste do jaji o tenham feito duvidar de sua própria inocência. Isso explicaria por que, depois da cerimônia acusatória, ele teria, segundo André de Medina e vários de seus escravos, confessado matar mais de quarenta escravos com feitiços, entre cativos pertencentes a André e a outros proprietários da vizinhança. Se era para Simão ser um feiticeiro, que fosse um temível e perigoso feiticeiro com um extenso currículo de mortes. De acordo com o testemunho de André, "dois anos depois que se fez a cerimônia referida, confessara o mesmo escravo Simão diante dele testemunha que era verdade que ele matara aos seus quinze escravos, e [...] aquela confissão não fazia ele voluntariamente, senão obrigado de uns bichos que the ferviam na cabeça." ${ }^{19}$

A misteriosa referência aos "bichos" que ferviam na cabeça de Simão permite múltiplas leituras, em diferentes camadas. Num primeiro sentido, os "bichos" podem simbolizar a própria influência espiritual e sobrenatural de Grácia sobre a mente de Simão, que, à semelhança de uma manipulação psicológica de natureza mágica, teria levado o acusado a confessar seus crimes. Do ponto de vista psicológico de Simão, porém, os "bichos" talvez fossem manifestação de um sentimento de culpa ou de ambivalência, com o qual ele não conseguia lidar adequadamente. Parecia-lhe seguro e certo que não havia feito nenhuma cerimônia para causar doenças e matar seus companheiros de cativeiro - ele que já fora escravizado -, motivo pelo qual ele insistia em que não fazia a confissão voluntariamente, e continuou negando até o fim a acusação. Porém, algo lhe perturbava a mente, impedindo-o talvez de pensar com clareza. Seria seu sentimento de culpa? Sinal de que ele de fato atentara contra a segurança e o bem-estar dos escravos?

Levando a sério suas repetidas manifestações de inocência, talvez possamos encontrar o fundamento de sua culpa, e o motivo pelo qual the "ferviam bichos na cabeça" por um caminho indireto, a partir do que ele próprio confessou aos inquisidores. A uma determinada altura do interrogatório de Simão, após a primeira sentença provisória que o inocentava, os inquisidores questionaram novamente o réu se ele suspeitava do motivo pelo qual havia sido acusado pelos escravos de André Gomes de Medina. A pergunta fazia parte do procedimento inquisitorial: quando as denúncias contra um réu eram consideradas insuficientes ou inadequadas (como era o caso), isso frequentemente refletia o fato de que os denunciantes teriam motivos pessoais para acusar injustamente o réu. Desvendar essas motivações pessoais por trás das denúncias era parte do procedimento judicial para considerá-las nulas. Pressionado, Simão declarou que "não entende, nem pode alcançar a causa por que contra ele disseram semelhante mentira, e somente presume que serão alguns pretos invejosos da fortuna de o verem na sua liberdade." 20 Sua culpa, portanto, seria o fato de ele ser liberto, ao contrário dos demais que o acusavam. Haveria aí uma "inveja" (como ele afirmava) ou um ressentimento dos escravos contra antigos companheiros de cativeiro que haviam alcançado a liberdade, denotando conflitos insolúveis e linhas de fratura que dividiam a comunidade africana entre escravos e libertos no final do século $X V I I$, e davam ensejo a conflitos que podiam inclusive se desenrolar até a forma extrema de perseguições e suplícios públicos e coletivos (como foi o caso na propriedade de André Gomes de Medina)? 
A existência de clivagens e fronteiras no seio das comunidades africanas é questão recorrente na historiografia brasileira da escravidão, e a discrepância de oportunidades e situação social entre escravos e libertos (ou, analogamente, entre africanos e crioulos, ou ainda entre africanos ladinos e boçais) já foi aventada como um dos mais importantes fatores de divisão interna das comunidades de africanos e afrodescendentes no Brasil, resultando num fator relativamente baixo de mobilização para a resistência contra a dominação senhorial e, portanto, numa maior estabilidade do sistema escravista (MATTOSO, 1990, p. 165; FARIA, 2007). Contrariamente a essa perspectiva, Robert Slenes sugeriu, a partir do contexto do oeste paulista no século XIX, que, dada a incerteza de sucesso da busca individual pela alforria, não parecia uma boa estratégia para os escravos potencialmente elegíveis à alforria distanciarem-se de seus companheiros de cativeiro com menos acesso aos privilégios seletivos outorgados pelos senhores em seu jogo de barganhas para controlar a escravaria. Sendo assim, a existência de uma estrutura de oportunidades desiguais não necessariamente implicaria a ausência de solidariedade entre os diversos grupos no interior da escravaria ou das comunidades africanas. Entre os centro-africanos de diferentes condições sociais, haveria crenças, costumes e concepções culturais compartilhadas que permitiam negociar solidariedades, vínculos e lideranças, inclusive em projetos de resistência contra o cativeiro (SLENES, 2007). Como o caso de Simão pode nos auxiliar nessa discussão?

Para James Sweet, o resultado da cerimônia de Grácia era uma solução estratégica para a comunidade de escravos: aparentemente, o rito acatava a decisão senhorial sobre o caso, acusando e "eliminando" um liberto que, portanto, não era propriedade nem capital da família Medina (embora se deva ressaltar que ele era um rendeiro da filha de André Gomes de Medina). Ao mesmo tempo, liberava as tensões no interior da comunidade escrava, acusando um "forasteiro" dos crimes cometidos e protegendo os escravos sobreviventes da fúria do senhor. Por fim, para Sweet, o resultado seria condizente com uma possível crença de que a situação de prosperidade de Simão poderia resultar de uma feitiçaria por ele praticada, já que as culturas centro-africanas frequentemente consideravam que o enriquecimento ilícito ou inexplicável podia ser explicado por feitiçaria, pela "canibalização" da força de terceiros pelo feiticeiro, como instrumento para incrementar sua própria força e posição social. Portanto, o julgamento expressaria uma síntese e uma "solução mutuamente satisfatória" para os imperativos africanos e luso-americanos (SWEET, 2003, p. 122)

A interpretação de Sweet sugere que a alforria teria sido encarada pelos centro-africanos como uma espécie de ascensão social ilícita, potencialmente identificável à feitiçaria, o que contradiz o fato de que inúmeros libertos centro-africanos eram vistos como legítimos, e inclusive assumiam posições de liderança social e religiosa no interior das comunidades africanas, como era o caso de inúmeros calunduzeiros que haviam conquistado sua liberdade por meio dos rendimentos obtidos com suas adivinhações e curas. Ademais, Simão dificilmente poderia ser considerado um "forasteiro" na comunidade de escravos de André de Medina, já que ele era roceiro de sua filha, Maria Cabral, e partilhava com os africanos da propriedade uma origem cultural e territorial semelhante. Portanto, para explicarmos adequadamente as tensões entre Simão e os africanos de André de Medina, é preciso aprofundar um pouco mais a análise e retornar a um detalhe curioso do processo 
inquisitorial de Simão, que havíamos deixado em suspenso anteriormente: as reiteradas descrições de Simão, por parte das testemunhas do processo, como um "escravo" de Maria Cabral.

Simão foi claro a respeito de sua condição de alforriado em seu depoimento aos inquisidores:

Disse que, depois que veio para a Bahia, esteve cativo de André Machado [sabemos ainda, por outras partes do processo, que ele passou posteriormente para a posse de Manuel Madeira, genro de seu primeiro senhor]. Tinha exercício de andar catando para seu senhor, e depois que ficou forro passou a ser lavrador de mandioca. ${ }^{21}$

Não sabemos exatamente em que época nem sob que circunstâncias Simão conquistou sua alforria. A julgarmos por sua críptica referência a seu ofício em sua época de escravo (o "exercício de andar catando"), podemos imaginar que Simão não era um escravo do eito, e talvez gozasse de um certo grau de mobilidade que lhe permitia acumular pecúlio para comprar sua alforria. Nesse sentido, talvez ele fosse um desses ladinos "privilegiados" em relação aos escravos da lavoura, com maiores perspectivas de alcançar a liberdade jurídica. Contudo, é sabido que a liberdade jurídica nem sempre correspondia à liberdade de fato. A sociedade escravista luso-americana, longe de estar dividida de forma binária por uma linha jurídica que separava os escravos dos livres em dois grupos rígidos e absolutos, caracterizava-se por um amplo espectro de condições de dependência vivenciadas a partir de acordos pessoais que se perpetuavam, inclusive para os libertos recém-egressos do cativeiro (LARA, 1988). Mais um motivo, aliás, para desconsiderarmos a hipótese de um antagonismo irredutível entre escravos e libertos no seio da comunidade africana de Santo Amaro da Pitanga.

Essa noção de um espectro contínuo de condições de dependência e cativeiro, no lugar de uma clivagem jurídica binária, ajustava-se não apenas à prática social corrente no mundo escravista luso-americano, como também às concepções africanas da escravidão. Como ressaltou Claude Meillassoux (1995), nas sociedades africanas tradicionais da costa atlântica, fortemente estruturadas pelo parentesco, a condição que mais se aproximava da noção europeia de escravo era a do "estranho", ou seja, o indivíduo sem parentela. Nesse universo social, na medida em que o parentesco era a principal instância de atribuição de posições sociais e direitos aos indivíduos (RADCLIFFE-BROWN, 1973, p. 46-66), era necessário pertencer a alguma linhagem para gozar dos direitos e benefícios que lhe eram correspondentes, tais como o acesso à terra, à distribuição da produção econômica ou ao casamento. Num tal cenário, o forasteiro que não possuísse parentela na localidade onde residia precisava necessariamente se colocar sob a influência de algum patrono para obter condições de sobrevivência mínimas. Não tendo outros parentes a quem recorrer, tornava-se dependente exclusivo de seu patrono, sendo essa precisamente a condição do "escravo" nas sociedades africanas tradicionais. À medida que esse "estranho/escravo" começava a se integrar às linhagens locais, por meio do matrimônio ou da descendência, sua condição de marginalidade iria se atenuando gradualmente ao longo do tempo, até que seus descendentes se tornassem membros com plenos direitos nas comunidades. 
À medida que o comércio de escravos se estruturava e ganhava importância econômica e política na costa atlântica africana, no período que se estende entre os séculos XV e XIX, muitas sociedades costeiras vivenciaram uma transição social, de um modelo de "sociedades com escravos" (em que eventuais forasteiros eram progressivamente incorporados nos moldes descritos) para um modelo de "sociedades escravistas", que dependiam da existência e da perpetuação social da escravidão, e que elaboraram modelos para a reprodução social da condição do escravo, frequentemente pelas restrições aos mecanismos de integração nas linhagens locais (MEILLASSOUX, 1995; LOVEJOY, 2002). Nos territórios atlânticos da África Centro-Ocidental, de onde provinham Simão, Grácia e a maior parte da escravaria africana dos Medina, esse processo deu origem a sociedades costeiras (como o reino do Congo ou os sobados avassalados do antigo reino do Ndongo, em Angola) em que um grande número de escravas mulheres, importadas do interior, era mantido em situação de dependência de patronos africanos poderosos a fim de gerar uma prole sem parentela (já que a maior parte dos direitos, nessas sociedades, era herdada pela linha materna), que pudesse ser vendida aos mercadores atlânticos de escravos (MILLER, 1988, p. 126-135).

Considerando a disseminação de uma estrutura social que apresentava vários níveis de dependência como resultado da ausência de vínculos parentais na África Centro-Ocidental do século XVII, seria bastante familiar aos escravos centro-africanos comercializados para as Américas a noção de um espectro progressivo de condições de dependência e autonomia que se faria pela constituição de novos vínculos sociais com patronos, comunidades, instituições e famílias influentes. De fato, como sugere Joseph Miller (2004), as identidades e as estratégias de autonomia de centro-africanos na América Portuguesa se construíam pela tentativa de ingresso em grupos e instâncias de pertencimento múltiplos e alargados, buscando uma acumulação de recursos e "direitos" adquiridos por meio da inserção em diferentes círculos sociais, numa tentativa de atenuar a vulnerabilidade advinda de uma situação de "estraneidade" e isolamento social.

Se Simão era de fato portador jurídico de sua liberdade, não era assim que ele era socialmente reconhecido. Quando Grácia chegou para julgá-lo, ele se encontrava preso a um tronco à espera de seu julgamento, tal qual um escravo à espera de punição. André Gomes de Medina declarou ao Santo Ofício que Simão era escravo de sua filha, Maria Cabral, informação corroborada pelo padre Martim Pessoa e por sua outra filha Bárbara Cabral. O que era ainda mais significativo é que a descrição de Simão como cativo ("escravo de uma Maria Cabral")22 foi corroborada também por uma escrava de André Gomes de Medina chamada Úrsula Gomes. Não eram apenas os membros da família Medina que o viam como escravo: essa parecia ser também a percepção dos próprios cativos de André Medina, em consonância com a concepção tradicional africana da condição do "escravo" como o dependente exclusivo de um único patrono poderoso - que, no caso, seria Maria Cabral. Ele não estava sendo acusado pela escravaria como um "forasteiro" liberto, mas como um igual. Ou melhor: não exatamente como um "igual", como veremos, mas como alguém de condição social semelhante ou, ao menos, análoga.

Não é difícil explicar essa situação de Simão, na verdade. É bem provável que, num ambiente rural como o da freguesia de Santo Amaro da Pitanga, um liberto sem pecúlio 
significativo não tivesse muitas possibilidades de sustento material, a não ser que se colocasse sob a influência e a dependência de um patrono proprietário de terras que the arrendasse um bocado de terra para constituir uma lavoura. Parecia ser exatamente esse o caso de Simão, que se tornou lavrador de mandioca nas terras da família Medina. Isso explicaria por que ele era reconhecido como "escravo" de Maria Cabral, já que dependia da permissão da proprietária (e, portanto, indiretamente também da permissão de seu pai André Gomes de Medina) para adquirir seu sustento material, e provavelmente era instado a fazer serviços pessoais para ela. Simão, embora juridicamente livre, vivia em uma condição de dependência tal, que era reconhecido como inteiramente subordinado aos desígnios e às vontades de Maria Cabral - como seu "escravo", em suma. Na perspectiva africana, sua condição de dependência (de "escravidão") não chegara a se atenuar significativamente após sua alforria. Talvez tenha até se acentuado, na medida em que ele deixou de pertencer a uma escravaria mais ampla para se colocar sob a influência pessoal, individual, de sua "senhora-arrendante" Maria Cabral.

Portanto, Simão não era nem um escravo como os demais, nem um africano livre que tivesse abandonado o cativeiro, a cujo exemplo os demais cativos pudessem aspirar. Ele ocupava uma dúbia e ambígua posição liminar, como a de alguém que havia cruzado duas vezes, em sentido reverso, a linha que separa os escravos dos libertos: tendo se tornado livre, voltou a se submeter à "escravidão" ao se tornar lavrador nas terras dos Medina. Era algo como um "reescravizado". Ele se encontrava dilacerado entre lealdades conflitantes: por um lado, era um africano como muitos dos escravos de André de Medina e havia se libertado mais ou menos recentemente do cativeiro; por outro, havia vindo de fora da propriedade e sua subsistência material dependia de que mostrasse lealdade e obediência a Maria Cabral, em detrimento de seus companheiros africanos. A "liberdade" tinha um gosto amargo para Simão: para sustentá-la, ele talvez tenha se visto forçado a demonstrar lealdade incondicional aos Medina, sendo visto pelos demais cativos da propriedade como alguém que passara ao "outro lado". Simão era um dos produtos daquele jogo de privilégios seletivos, oferecidos pelos senhores em troca de lealdades pessoais incondicionais, por meio do qual a classe senhorial intentava dividir a comunidade de africanos e de escravizados e garantir, assim, a estabilidade da ordem escravista (MARQUESE, 2006; FARIA, 2007). Seu "privilégio", efêmero e ilusório, fora também sua ruína: numa crise como a que a propriedade dos Medina vivenciava após a morte de tantos escravos, um africano liminar como Simão era a peça sobressalente que tanto os proprietários quanto os escravos estavam dispostos a sacrificar em prol do restabelecimento da ordem e de algum tipo de "normalidade" - ainda que essa normalidade pudesse assumir sentidos distintos para os proprietários e para os escravos africanos.

\section{Liberdade e solidariedade: dois paradigmas de oposição à escravidão}

Sugeri anteriormente que Grácia não havia sido convocada apenas para resolver o problema do senhor André Gomes de Medina, para quem a misteriosa morte dos escravos implicava uma enorme perda de capital e força produtiva. Grácia, afinal, fora indicada a André pelos seus cativos, de modo que ela também estava lá para atender aos seus interesses. Quais seriam esses? 
Num primeiro nível de leitura, é evidente que os escravos sobreviventes dos Medina deviam estar vivenciando um sentimento de terror constante devido ao medo de novas mortes por feitiçaria, e provavelmente clamavam pela intervenção de alguém que pudesse interromper essa feitiçaria e restabelecer a "saúde" da comunidade em crise - alguém capaz de regenerar os vínculos entre os vivos e os espíritos. Na concepção centro-africana, como vimos, uma tragédia dessas proporções só poderia ser adequadamente explicada pela existência de uma feitiçaria que estivesse perturbando o bem-estar coletivo da comunidade. Nesse sentido, a convocação de uma calunduzeira era uma atitude muito consequente com esses anseios, permitindo eliminar a fonte do mal. Além disso, também não é difícil imaginar que os parentes dos escravos supostamente mortos por feitiços ansiassem por vingança contra o feiticeiro que havia sido responsável. Para isso, também, uma cerimônia de caráter punitivo como o jaji parecia uma ótima solução.

Mas não se tratava de punir qualquer bode expiatório. A acusação tinha endereço certo: Simão, o alforriado que, depois de liberto, se submetera aos senhores de escravos. Simão, a quem a alforria, depois de separá-lo dos outros africanos, tornara ainda "mais escravo" que os demais cativos. Simão não estava sendo acusado por ser liberto, ao contrário do que presumia e alegou aos inquisidores; pelo contrário, ele parecia estar sendo acusado por ser escravo mesmo após a liberdade, e por ter abandonado os irmãos de cativeiro para passar para a esfera de influência pessoal da senhora Maria Cabral. Nesse sentido, talvez os demais escravos da região o olhassem menos com "inveja" (como ele declarou aos inquisidores) e mais com rancor - sentimentos perigosamente próximos, como sabemos. Sua "feitiçaria" não consistia simplesmente em ter obtido ascensão social e conquistado a alforria: mais que isso, ela advinha do fato de que ele havia "virado as costas" a seus companheiros africanos - ou assim eles o entendiam - para se tornar o "escravo pessoal" de Maria Cabral. A cerimônia de Grácia era um acerto de contas: se Simão estava dividido entre lealdades conflitantes para com sua beneficiária Maria Cabral e para com os escravos da propriedade, o jaji dramatizou publicamente essas tensões afetivas latentes e convocou Simão de volta à lealdade em relação aos escravizados africanos. Ele falhou no teste - se é que ainda tinha alguma chance de sucesso. Talvez, àquela altura, depois de tantas mortes e desgraças, já fosse tarde demais para reatar os laços rompidos pela malícia das estratégias senhoriais.

Condenado pelos escravos, por André de Medina e por Grácia, Simão foi denunciado ao Santo Ofício na esperança de que o tribunal inquisitorial cuidasse da execução da sentença por um "crime" que era, em verdade, alheio à jurisdição inquisitorial. Os inquisidores não deixaram de perceber essa manipulação do procedimento jurídico, rejeitando as denúncias e inocentando Simão de todas as acusações. Talvez, nesse cabo de forças entre diferentes instâncias de justiça (a justiça centro-africana tradicional, a justiça senhorial e a justiça eclesiástica), Simão tenha na prática saído ileso. Mas não saiu incólume. Sua fidelidade ao jogo da classe senhorial custou-lhe, no fim das contas, o repúdio dos escravos, a acusação pública e a prisão durante quatro anos nos cárceres eclesiásticos. Mas nada disso se comparava àquele que era o custo mais alto de seus atos: a consciência pesada, fervendo como bichos em sua cabeça.

Nunca saberemos que ações concretas Simão terá tomado para suscitar tamanho rancor e indisposição entre os escravos de André de Medina. Talvez tenha parecido se 
portar de uma maneira excessivamente submissa a Maria Cabral. Talvez tenha tido conflitos de interesses, pequenos desentendimentos pelos direitos de uso da terra, ou quem sabe apenas provocações recíprocas com escravos das propriedades da família Medina. Talvez tenha sido difamado pelos escravos de André Machado ou Manuel Madeira, seus antigos senhores. Talvez a alforria o tenha deixado um pouco presunçoso mesmo. Ou talvez tenha simplesmente sido vítima de tempos sombrios, em que a morte rondava as terras e os escravos dos Medina, causando pânico e suscitando caças às bruxas. O fato é que sua posição social liminar - ao mesmo tempo liberto e escravo, "parente" e "estranho" em relação aos demais cativos e africanos da propriedade - selou seu destino nesse contexto extraordinário da freguesia de Santo Amaro da Pitanga em meados da década de 1680.

O episódio da condenação de Simão por Grácia e pelos escravos de André Gomes de Medina nos oferece material de reflexão para especular sobre a forma como os cativos africanos (e, neste caso, especificamente os centro-africanos) encaravam seu cativeiro e buscavam saídas para a situação de marginalidade e sofrimento que vivenciavam. A reflexão nos leva a uma temática frequentemente explorada na historiografia da escravidão: o problema da resistência escrava. Por muito tempo, historiadores e sociólogos brasileiros imaginaram que a resistência oferecida pelos escravos a seus senhores só poderia assumir o aspecto de oposição frontal e violenta ao sistema escravista e de busca incondicional pela liberdade, por meio de manifestações extremas como a fuga, os quilombos ou as rebeliões (MOURA, 1972). Tratava-se de uma reação contra uma geração de intelectuais brasileiros (entre os quais figura Gilberto Freyre (1984)) em cujas obras a resistência escrava assumiu papel minoritário.

Mais recentemente, a chamada "história social da escravidão" ressaltou a multiplicidade de formas de resistência exercidas pelos escravos ao longo de mais de três séculos de escravidão africana no Brasil. No lugar da antiga dicotomia entre atitudes passivas e submissas de "acomodação" e atitudes rebeldes e ativas de "resistência" por parte dos escravos, emergiu nessa historiografia, produzida majoritariamente entre as décadas de 1980 e 1990, uma noção de "negociação" como arranjo tenso, circunstancial, conflituoso e marcado por pressões contínuas tanto do lado senhorial como do lado dos escravos, encetando uma multiplicidade de formas de resistência exercidas por escravos, nem sempre no sentido de oposição frontal ao sistema, mas muitas vezes como estratégias para demandar e obter concessões senhoriais significativas e melhorias concretas nas condições cotidianas de vida dos cativos (LARA, 1988; REIS; SILVA, 1989; MATTOSO, 1990; SLENES, 2011).

Apesar de ter abandonado uma moldura dicotômica rígida no tratamento conceitual do tema da resistência escrava, parte substancial dessa historiografia continuou pensando a conquista da liberdade como horizonte final ou como "ponto de fuga" dessas negociações realizadas pelos escravos. Para Eduardo Silva e João Reis, por exemplo, negociações e ajustes cotidianos emergiam como um espaço "intermediário" entre a submissão e a rebeldia aberta, em grande medida devido ao entendimento de que as formas frontais de oposição (a rebelião e a fuga permanente) eram significativamente dificultadas pelo "paradigma ideológico colonial" (SILVA; REIS, 1989, p. 66), que prescrevia lugares e posições sociais que pressupunham a existência continuada da escravidão. Apesar de estatisticamente menos 
frequente, a oposição frontal, sob a forma de quilombos e rebeliões, seria um "trunfo" a ser manipulado pelos escravos, constituindo um fantasma constantemente presente nas ameaças de cativos e nas consciências de proprietários e forçando a classe senhorial a fazer as pequenas concessões cotidianas que predominavam nos arranjos das relações senhoriais.

Esses arranjos e concessões, por sua vez, eram justamente o que dava estabilidade às relações escravistas a longo prazo: as alforrias, por exemplo, constituíam uma importante válvula de escape de tensões sociais, coibindo por vezes a emergência de confrontos diretos (MARQUESE, 2006). Desse modo, as pressões dos escravos pela liberdade podem ser encaradas, dialeticamente, como parte constitutiva dos próprios limites, estratégias e formas da dominação senhorial (LARA, 1988). Em algumas análises, as negociações cotidianas surgem como estratégia possível diante das barreiras à conquista da liberdade e das dificuldades impostas aos planos de rebelião (REIS; SILVA, 1989, p. 14). ${ }^{23}$ Em outros autores vinculados a essa historiografia, a rebeldia aberta é interpretada como um recurso extremo e desesperado de escravos (majoritariamente africanos) incapazes de se adaptar às formas mais usuais de negociação (MATTOSO, 1990). Em qualquer caso, o horizonte final das negociações entre senhores e escravos aponta, quase sempre, para a conquista da liberdade como ideal paradigmático almejado pelos cativos africanos no Brasil. ${ }^{24}$

Qualquer que seja o caso, a liberdade continua quase sempre sendo o peso e a medida a partir das quais as formas de resistência escrava podem ser aquilatadas, como se ela fosse o horizonte inescapável das ações e dos projetos de vida dos escravos, considerados coletivamente. Para nós, leitores e historiadores do século XXI, parece óbvio e natural que os escravos rejeitassem a condição social em que viviam, e lutassem contra ela. E a noção de que dispomos para opor à escravidão, de dentro das ideologias liberais ou revolucionárias da modernidade, é o conceito de liberdade, definido majoritariamente em termos de um ideário ilustrado. Diante do pressuposto de que os escravos deviam se opor ao cativeiro de que eram vítimas, e frente às dificuldades para compreender o universo mental dos cativos africanos, tendemos a projetar sobre suas consciências uma forma de oposição e crítica à escravidão que deriva, em última instância, do nosso ideário moderno, e que consiste na maneira como definimos um certo conceito de "liberdade". Conforme a instigante e perturbadora sugestão do antropólogo Louis Dumont (1992), o ideário ilustrado da modernidade, baseado em noções abstratas de individualismo e igualitarismo, nos mune de tantos pressupostos sobre como funciona (e/ou deveria funcionar) a vida social, que temos dificuldade em conceber universos culturais divergentes. No caso da história da escravidão, corremos o risco de ficarmos cegos para ideais e paradigmas de oposição ao cativeiro que não estejam formulados no solo conceitual do igualitarismo moderno, com sua insistência na garantia dos direitos individuais à liberdade.

No caso dos ideais de bem-estar social expressos pela comunidade de escravos reunidos em torno da cerimônia judiciária de Grácia, talvez estejamos diante de uma dessas críticas "não ilustradas" à escravidão. ${ }^{25}$ Ao constatar a veemente condenação da "liberdade" de Simão pelos escravos, podemos perceber como é perigoso imaginar que a liberdade, definida em termos jurídicos limitados, figurasse no topo da hierarquia de valores perseguidos pelas comunidades de africanos escravizados da América Portuguesa. 
Em alguns casos, inclusive, parece que essa ilusória liberdade podia ser mesmo ativamente rechaçada pelos cativos. Era o caso, sobretudo, quando se tratava de uma liberdade que implicasse a ruptura dos vínculos comunitários internos aos africanos e seus descendentes, uma liberdade que engendrasse a reiterada divisão interna do grupo dos escravos e dos africanos e o colocasse entre lealdades conflitantes, ao sabor das estratégias de dominação senhoriais que ofereciam privilégios seletivos como forma de incentivar disputas e dissidências entre escravos de diferentes condições sociais. O que a comunidade escrava de Santo Amaro da Pitanga parecia refutar, em suma, era uma liberdade que se impusesse em detrimento de relações de solidariedade no interior do grupo.

Reclamava-se a possibilidade de estabelecimento de uma comunidade de escravos em torno de um ideal de solidariedade entre todos aqueles submetidos ao cativeiro, contra as tendências centrífugas suscitadas pelas estratégias senhoriais de controle. Sheila Faria (2007), em um balanço da historiografia sobre as relações internas entre grupos de escravos, ressaltou a impossibilidade de constituição de uma única "comunidade" escrava unificada, em grande medida devido às tensões internas incentivadas pela classe senhorial. A autora apontou, alternativamente, para a constituição de uma multiplicidade de comunidades limitadas, cuja abrangência dependia da heterogeneidade cultural e linguística dos escravos e das situações de enfrentamento contra os senhores. Robert Slenes (2007), por sua vez, apontou a existência de canais e linguagens culturais (entre os quais a religiosidade) por meio dos quais as tensões sociais internas às escravarias podiam ser atenuadas, e novas solidariedades transversais podiam ser negociadas. O julgamento de Grácia e a atribuição de uma "culpa" a Simão parecem fazer parte desse conjunto de estratégias de reforço de um ideal de solidariedade que permitia negociar cotidianamente as relações internas às comunidades escravas, ao menos no seio dos escravizados centro-africanos, que eram capazes de entender as concepções cosmológicas subjacentes aos ritos de Grácia.

Em trabalho em que abordei cerimônias de calunduzeiros como Grácia no Recôncavo Baiano nas últimas décadas do século XVII, observei a noção disseminada de que a escravidão parecia suscitar nos escravizados centro-africanos uma "doença" que demandava tratamento ritual pelos calunduzeiros. Essa doença, que era chamada pelo nome de "calundu", ${ }^{26}$ era causada pelos espíritos dos ancestrais do doente, que afligiam espiritualmente seus descendentes por não receberem mais o culto adequado no seio das linhagens africanas. Nesse sentido, a doença era provocada pela maneira como o comércio de escravizados destruía os vínculos entre os centro-africanos, sua parentela africana e seus antepassados, dissolvendo comunidades parentais e criando indivíduos isolados, sem parentes - ou seja, "escravos" na concepção africana tradicional (MARCUSSI, 2015). Para esses cativos, portanto, o contrário da escravidão não era a "liberdade" (garantida como direito individual). A rigor, uma tal noção de liberdade como direito individual só confirmaria o mal-estar de uma ausência de formas coletivas de solidariedade. Parecia ser esse também o sentimento expresso na condenação da condição social de Simão por seus companheiros de cativeiro. As formas de sensibilidade cristalizadas em torno de cerimônias como os calundus de Grácia e de outros sacerdotes centro-africanos na América Portuguesa talvez possam apontar para outras concepções de resistência e para outros projetos políticos defendidos pelos africanos no cativeiro, que não passavam necessariamente pela noção moderna de "liberdade" e que estavam situados fora dos 
limites estreitos nos quais a ideologia liberal confinou o horizonte conceitual possível de oposição ideológica à escravidão. É tarefa dos historiadores compreender esses outros horizontes antiescravistas para que sejamos capazes de reimaginar, junto com os africanos escravizados, os regimes possíveis da liberdade.

\section{REFERÊNCIAS}

Arquivo Nacional da Torre do Tombo, Tribunal do Santo Ofício, Inquisição de Lisboa, proc. 8464.

Arquivo Nacional da Torre do Tombo, Tribunal do Santo Ofício, Inquisição de Lisboa, proc. 11163.

BETHENCOURT, Francisco. História das Inquisições: Portugal, Espanha e Itália: séculos XV-XIX. São Paulo: Companhia das Letras, 2000.

CAVAZZI DE MONTECÚCCOLO, Padre João António. Descrição histórica dos três reinos do Congo, Matamba e Angola. Trad., notas e índice pelo Padre Graciano Maria de Leguzzano. Lisboa: Junta de Investigações do Ultramar, 1965. 2v.

CRAEMER, Willy de; VANSINA, Jan; FOX, Renée C. Religious Movements in Central Africa: A Theoretical Study. Comparative Studies in Society and History, Cambridge: Cambridge University Press, v. 18, n. 4, p. 458-475, oct. 1976.

DUMONT, Louis. Homo hierarchicus: o sistema das castas e suas implicações. São Paulo: EDUSP, 1992

FARIA, Sheila de Castro. Identidade e comunidade escrava: um ensaio. Tempo, Rio de Janeiro: Universidade Federal Fluminense, v. 11, n. 22, 2007, p. 122-146.

FREYRE, Gilberto. Casa-grande \& senzala: formação da família brasileira sob o regime da economia patriarcal. 23ํㅡ ed. Rio de Janeiro: José Olympio, 1984.

KANANOJA, Kalle. Pai Caetano Angola, Afro-Brazilian Magico-Religious Practices, and Cultural Resistance in Minas Gerais in the Late Eighteenth Century. Journal of African Diaspora Archaeology and Heritage,Walnut Creek (EUA): Left Coast Press, v. 2, n. 1, p. 1837, maio 2013.

LARA, Silvia Hunold. Campos da violência: escravos e senhores na capitania do Rio de Janeiro, 1750-1808. Rio de Janeiro: Paz e Terra, 1988.

LÉVI-STRAUSS, Claude. Antropologia estrutural. Rio de Janeiro: Tempo Brasileiro, 1985.

LOVEJOY, Paul E. A escravidão na África: Uma história de suas transformações. Rio de Janeiro: Civilização Brasileira, 2002. 
MACGAFFEY, Wyatt. Religion and Society in Central Africa: The BaKongo of Lower Zaire. Chicago/London: The University of Chicago Press, 1986.

MARCOCCl, Giuseppe. Os segredos do coração: confissão e inquisição. Lisboa, 18 set. 2012. Palestra proferida no Seminário de História Religiosa Moderna, organizado pelo Centro de Estudos de História Religiosa da Universidade Católica Portuguesa.

MARCUSSI, Alexandre Almeida. Cativeiro e cura: experiências da escravidão atlântica nos calundus de Luzia Pinta, séculos XVII-XVIII. São Paulo, 2015. 510 f. Tese (Doutorado em História Social) - Faculdade de Filosofia, Letras e Ciências Humanas, Universidade de São Paulo.

MARQUESE, Rafael de Bivar. A dinâmica da escravidão no Brasil: resistência, tráfico negreiro e alforrias, séculos XVII a XIX. Novos estudos CEBRAP, São Paulo, n. 74, p. 107123, mar. 2006.

MATTOSO, Kátia de Queirós. Ser escravo no Brasil. 3a ed. São Paulo: Brasiliense, 1990.

MEILLASSOUX, Claude. Antropologia da escravidão: o ventre de ferro e dinheiro. Trad. Lucy Magalhães. Rio de Janeiro: Jorge Zahar Editor, 1995.

MILLER, Joseph. Retention, Reinvention, and Remembering: Restoring Identities Through Enslavement in Africa and under Slavery in Brazil. In: CURTO, José C.; LOVEJOY, Paul. Enslaving Connections: Changing Cultures of Africa and Brazil during the Era of Slavery. New York: Humanity Books, 2004, p. 81-121.

Way of death: Merchant Capitalism and the Angolan Slave Trade: 1730-1830. Madison, EUA: The University of Wisconsin Press, 1988.

MOURA, Clóvis. Rebeliões da senzala: quilombos, insurreições, guerrilhas. $2^{a}$ ed. rev. e ampl. Rio de Janeiro: Editora Conquista, 1972. (Coleção Temas Brasileiros, 11)

NOGUEIRA, André Luís Lima. Doenças de feitiço: as Minas setecentistas e o imaginário das doenças. Varia Historia, Belo Horizonte: UFMG, v. 38, n. 47, p. 259-278, jan.-jul. 2012.

NOVINSKY, Anita Waingort. A inquisição. São Paulo: Brasiliense, 1994.

RADCLIFFE-BROWN, Alfred Reginald. Estrutura e função na sociedade primitiva. Petrópolis: Vozes, 1973.

REIS, João José. Magia jeje na Bahia: a invasão do calundu do Pasto de Cachoeira, 1785. Revista Brasileira de História, São Paulo: ANPUH, v. 8, n. 16, p. 57-81, mar.-ago. 1988.

REIS, João José; SILVA, Eduardo. Negociação e conflito: a resistência negra no Brasil escravista. São Paulo: Companhia das Letras, 1989.

RIBEIRO, Márcia Moisés. Exorcistas e demônios: demonologia e exorcismos no mundo luso-brasileiro. Rio de Janeiro: Campus, 2003. 
SARAIVA, António José. Inquisição e cristãos-novos. Lisboa: Editorial Estampa, 1985.

SLENES, Robert. W. L'arbre nsanda replanté: cultes d'affliction Kongo et identité des esclaves de plantation dans le Brésil du Sud-Est (1810-1888). Cahiers du Brésil Contemporain, Paris: Maison des Sciences de l'Homme, n. 67/68, v. 2, p. 217-313, 2007.

Na senzala, uma flor: esperanças e recordações na formação da família escrava: Brasil sudeste, século XIX. 2. ed. corrig. Campinas, SP: Editora da Unicamp, 2011.

SOUZA, Laura de Mello e. O diabo e a Terra de Santa Cruz: Feitiçaria e religiosidade popular no Brasil colonial. São Paulo: Cia. das Letras, 1986.

Revisitando o calundu. In: GORENSTEIN, Lina e CARNEIRO, Maria L. Tucci (Org.). Ensaios sobre a intolerância: Inquisição, Marranismo e Anti-Semitismo. São Paulo: Humanitas, 2002, p. 293-317.

SWEET, James Hoke. Domingos Álvares, African healing, and the intellectual history of the Atlantic World. Chapel Hill: The University of North Carolina Press, 2011.

Recreating Africa: Culture, Kinship, and Religion in the African-Portuguese World, 1441-1770. Chapel Hill: University of North Carolina Press, 2003.

THORNTON, John K. A África e os africanos na formação do mundo Atlântico: 14001800. Rio de Janeiro: Elsevier, 2004.

Religious and Cremonial Life in the Kongo and Mbundu Areas, 1500-1700. In: HEYWOOD, Linda (Ed.). Central Africans and cultural transformations in the American diaspora. Cambridge: Cambridge University Press, 2002, p. 71-90.

VOYAGES: The Trans-Atlantic Slave Trade Database. In: EMORY UNIVERSITY. Disponível em: <http://www.slavevoyages.org/>. Acesso em: 26 set. 2017. 


\section{Notas}

1 Note-se que a dimensão pública dos autos de fé da Inquisição portuguesa esteve em declínio após um incidente envolvendo disputas por precedência entre nobres portugueses na cerimônia de 1683, as quais culminaram em uma briga armada que quase possibilitou a fuga dos prisioneiros inquisitoriais (BETHENCOURT, 2000, p. 268). Depois disso, aumentou a proporção de autos de fé realizados dentro das igrejas, ainda que públicos. $O$ auto de fé privado de Simão, em 1689, ocorreu nesse contexto de retraimento das cerimônias aos espaços eclesiásticos.

2 Arquivo Nacional da Torre do Tombo (doravante ANTT), Tribunal do Santo Ofício, Inquisição de Lisboa, proc. 8464, fl. 52. 3 Há um debate na historiografia sobre a escravidão no Brasil a respeito do emprego dos termos "escravo(a)" e "escravizado(a)". Nota-se uma tendência recente que consiste em substituir o primeiro pelo segundo, sempre que possivel, com o intuito de rejeitar a desumanização dos indivíduos submetidos ao cativeiro e ressaltar o processo pelo qual a condição do escravo é socialmente produzida por meio de práticas de dominação. É preciso considerar, no entanto, que a generalização do termo "escravizado(a)" para designar a totalidade dos cativos elide a heterogeneidade interna aos grupos de escravos na América portuguesa. Africanos recém-chegados, africanos ladinos, crioulos e mulatos não compartilhavam as mesmas condições sociais, o que impactava suas experiências e vivências pessoais do cativeiro e suas estratégias de enfrentamento e resistência (LARA, 1988). Especificamente, a extensão do termo "escravizado(a)" para a totalidade dos cativos ignora as diferenças cruciais na experiência de individuos capturados no continente africano e vendidos pelo comércio atlântico de escravos em comparação com os indivíduos já nascidos em cativeiro na América portuguesa, os chamados "crioulos" e "mulatos", subdimensionando também os constantes atritos entre africanos e crioulos. Na medida em que este artigo visa apreender percepções do cativeiro e noções de liberdade e solidariedade que são específicas dos africanos (e não necessariamente extensiveis para os escravos nascidos na América), optei por empregar o termo "escravizado(a)" para me referir exclusivamente aos indivíduos que haviam vivenciado o processo de captura e privação da liberdade no continente africano, incluindo os africanos escravizados que depois conquistaram sua alforria (como é o caso de Simão). O termo "escravizado(a)", portanto, é empregado aqui para fazer referência à experiência da privação de direitos pessoais para os africanos, enquanto o termo "escravo(a)" refere-se à condição jurídica dos indivíduos e também é usado para designar o conjunto dos cativos, independentemente de sua origem ou condição de nascimento.

4 Outro caso de uma escrava que foi absolvida de culpas de feitiçaria na Inquisição de Lisboa, bem conhecido na historiografia, é o de Luzia da Silva Soares, escrava crioula residente em Ribeirão do Carmo, Minas Gerais, longamente torturada e supliciada pelos seus proprietários antes de ser processada pela Inquisição de Lisboa entre 1739 e 1745. Cf. ANTT, Tribunal do Santo Ofício, Inquisição de Lisboa, proc. 11163. É interessante observar as semelhanças entre o processo de Luzia e o de Simão: nos dois casos, eles foram previamente julgados e condenados por proprietários de escravos antes de serem remetidos à Inquisição, e a absolvição de ambos pode ser atribuída à percepção inquisitorial de que seus acusadores estavam usurpando as atribuições do tribunal. Para uma análise do caso de Luzia da Silva Soares, cf. SOUZA, 1986, p. 345-352.

5 ANTT, Tribunal do Santo Ofício, Inquisição de Lisboa, proc. 8464, fl. 27v.

6 No início do século XVIII, o comércio de escravos na Bahia tinha demanda prioritária por escravos homens entre 10 e 15 anos de idade (SWEET, 2011, p. 29; muito embora MATTOSO, 1990, p. 86 nos apresente uma pirâmide de idades distinta, sem especificar a época); portanto, é razoável supor que Simão fosse mais novo que isso ("muito menino") quando foi embarcado no continente africano. Fazendo-se uma estimativa conservadora de 10 anos para a idade com a qual ele foi embarcado, chega-se ao ano de 1658 como data plausivel de sua travessia atlântica. A base de dados Voyages: The Transatlantic Slave Trade Database (2017) não apresenta dados para a faixa etária dos escravos centroafricanos desembarcados na Bahia no período considerado. Note-se que a base de dados não apresenta informações sobre nenhuma viagem entre os portos centro-africanos e os portos baianos no período que se estende entre 1653 e 1664, período provável do desembarque de Simão. Há, portanto, três alternativas: ou Simão chegou à Bahia em 1653 portanto, com apenas 5 anos de idade ("muito menino") -, ou apenas depois de 1664 (com 14 anos ou mais, idade em que os escravos já não eram mais considerados "meninos"), ou então chegou em alguma viagem cujos dados não estão incluidos (a base de dados conta com informações sobre cerca de $81 \%$ do total de viagens realizadas).

7 Segundo André de Medina. ANTT, Tribunal do Santo Ofício, Inquisição de Lisboa, proc. 8464, fl. 14v.

8 Segundo o padre Martim Pessoa. Ibid., fl. 15v.

9 Para o significado do termo "quilundo", cf. Cavazzi de Monteúccolo (1965, v. 2, p. 209).

10 Ao longo do século XVIII, o termo "calundu" passou a ser usado mais amplamente para designar uma diversidade de cerimônias terapêuticas e divinatórias centro-africanas culturalmente aparentadas entre si, e deixou de estar vinculado especificamente aos falantes de quimbundo, abrangendo também os falantes de quicongo e até africanos de outras procedências geográficas. Kalle Kananoja (2013) e Laura de Mello e Souza (2002) argumentaram que, ao final do século XVIII, o termo passou a ser empregado para denominar quaisquer cerimônias religiosas africanas, mesmo que não estivessem necessariamente ligadas ao complexo ritualístico centro-africano, que era originalmente denominado por meio desse vocábulo. João José Reis (1988) analisou inclusive um caso de "calundu" baiano do final do século XVIII com prováveis origens culturais na região do golfo do Benim. Contudo, a análise formal que realizei sobre os calundus (MARCUSSI, 2015, p. 83-88) evidenciou uma razoável consistência cultural nos usos do termo "calundu" até o final do século XVIII, quando a palavra começou a cair em desuso.

11 ANTT, Tribunal do Santo Ofício, Inquisição de Lisboa, proc. 8464, fl. 33.

12 DA informação consta do testemunho da escrava Joana Dias, cujos pais e um sobrinho haviam sido supostamente enfeitiçados. Ibid., fl. 21v. -23.

13 Segundo a base de dados Voyages: The Transatlantic Slave Trade Database (2017), nas duas décadas que antecederam ○ julgamento de Simão (1665-1685), os africanos embarcados no porto de Luanda (majoritariamente falantes de 
quimbundo) representavam 35\% dos africanos desembarcados na Bahia, o que superava a porcentagem de africanos trazidos de quaisquer outras regiões da costa africana, consideradas individualmente. O predomínio de centro-africanos havia sido ainda mais acentuado nas décadas anteriores, já que o volume do comércio escravista entre a Bahia e o golfo do Benim cresceu exponencialmente nos dez anos imediatamente anteriores a 1685.

$14 \mathrm{lbid}$., fl. $14 \mathrm{v}$.

15 lbid., fl. 7

16 lbid., fl. $14 \mathrm{v}$

17 lbid., fl. 32-32v.

18 MacGaffey (1986, p. 164-165) descreve um caso ilustrativo que ele observou em seu trabalho de campo entre os bacongos na segunda metade do século XX. Segundo ele, uma mulher idosa chegou a uma cerimônia religiosa na iminência da morte, confessando ser uma feiticeira e ter sido responsável pela morte de uma pessoa. Em sonhos, ela fora enganada e levada a comer carne humana sem o saber, o que a transformara em uma feiticeira, já que o canibalismo é considerado a marca distintiva dos feiticeiros na cultura baconga. Ela alegava estar morrendo porque se recusara a compensar a feitiçaria cometida entregando um parente seu à família da vítima que ela supostamente teria enfeitiçado.

19 ANTT, Tribunal do Santo Ofício, Inquisição de Lisboa, proc. 8464, fl. 15.

20 lbid., fl. 43 (numerado como 21 no manuscrito).

$21 \mathrm{lbid}$., fl. 42 (numerado como 20 no manuscrito).

22 lbid., fl. $19 \mathrm{v}$

23 Ressalte-se a complexidade com que essa ideia aparece retratada na obra Negociação e conflito, de João José Reis e Eduardo Silva (1989): ora a negociação surge como forma possivel de adaptação diante da impossibilidade da rebelião, ora ela aparece como horizonte de possibilidades, demandas e exigências tornadas possiveis pela ameaça das rebeliões. Considere-se que a dupla autoria da obra (de João José Reis e Eduardo Silva) talvez ajude a explicar algumas oscilações no foco e no tom da argumentação - bem como, é claro, a complexidade e o caráter multifacetado da temática da negociação.

24 Convém destacar a exceção da forma como o tema é analisado na obra de Sílvia Lara, Campos da violência (1988). Para a autora, dominação, acomodação e resistência fazem parte de um sistema de arranjos conflituosos entre senhores e escravos, e os ajustamentos reciprocos entre as exigências de cada um dos grupos configuram os limites e as conformações da relação escravista, considerados legítimos tanto por senhores quanto pela maioria de seus cativos. Aqui, a conquista da liberdade e a ruptura definitiva com uma condição jurídica supostamente ilegítima da escravidão não aparecem como horizonte paradigmático da "agência" escrava.

25 James Sweet encarou a adivinhação centro-africana como uma "potente forma de resistência" (2003, p. 135, tradução minha) nas ocasiões em que brancos eram apontados como culpados - o que não foi o caso do julgamento de Simão. Contudo, o que estou sugerindo é que, mesmo nos casos em que outros africanos eram apontados como culpados, ritos como os de Grácia podiam oferecer um entendimento centro-africano acerca da escravidão e da liberdade e, assim, configurar um contradiscurso às práticas senhoriais dominantes.

26 "Calundu", portanto, emerge no último quartel do século XVII como termo quimbundo que designa simultaneamente uma doença e a cerimônia religiosa por meio da qual essa doença poderia ser curada.

\author{
Alexandre Almeida MARCUSSI. Professor Adjunto do Departamento de História da Faculdade \\ de Filosofia e Ciências Humanas da Universidade Federal de Minas Gerais. Av. Presidente \\ Antônio Carlos, n. 6627, 31270-901 Belo Horizonte, MG, Brasil. Pesquisa financiada pelo \\ CNPq e pela FAPESP.
}

